\title{
Pengaruh Terpaan Iklan dan Kesadaran Merek terhadap Keputusan Membeli Tiket Pesawat di Aplikasi TIKET.COM
}

The Effect of Advertising Exposure and Brand Awareness on the Decision to Buy Aircraft Tickets on The Tiket.Com Application

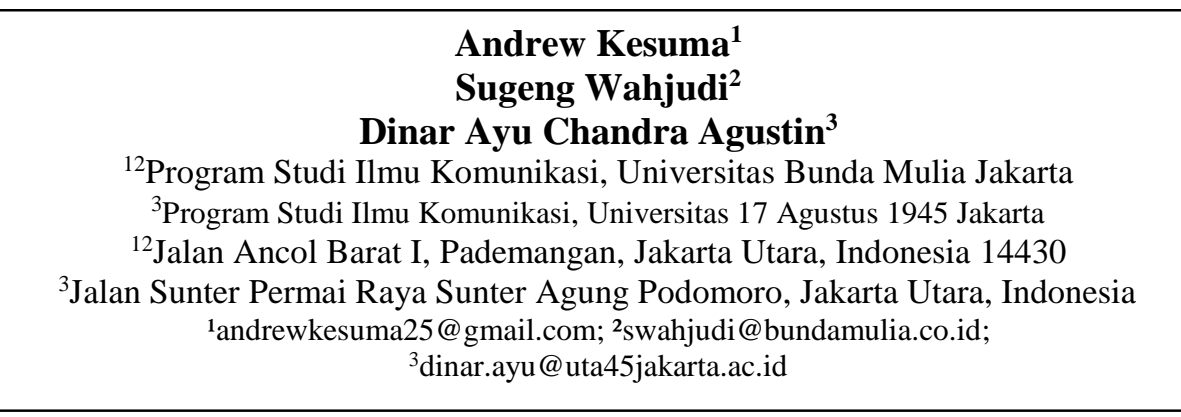

Dikirim: 29 November 2021, Direvisi: 27 Desember 2021, Diteriama: 27 Desember 2021, Terbit: 31 Desember 2021. Sitasi: Kesuma, Wahjudi, Agustin. (2021)., Pengaruh Terpaan Iklan dan Kesadaran Merek Terhadap Keputusan Membeli Tiket Pesawat di Aplikasi TIKET.COM, PRoMEDIA. Volume 7 (2), December 2021, hal 285- hal 320

\section{Abstract}

This study aims to analyze and explain: (1) the effect of advertising exposure on the decision to buy airline tickets on the Tiket.com application; (2) the Effect of Brand Awareness on the Decision to Buy Airline Tickets on the Tiket.com Application; (3) the influence of simultaneous advertising exposure and brand awareness on the decision to buy airline tickets on the Tiket.com application. This study uses a quantitative approach. The data collection used in this research is a survey method. The distribution of the questionnaire was carried out using Google Forms. The sample used is 100 respondents who are users of the tiket.com application set using the slovin formula. Data analysis using SPSS 25 program. The results and conclusions of this study show: (1) Based on the results of multiple correlation testing, simultaneously between the variables of Advertising Exposure and UNIVERSITAS 17 AGUSTUS 1945 JAKARTA 
Brand Awareness on Buying Decisions there is a close and strong relationship; (2) Based on the results of the regression test that has been done by the researcher, there is a positive effect. If Advertising Exposure increases, the decision to buy Airplane Tickets on the Tiket.com Application will also increase, as well as the increase in Brand Awareness will also increase the decision to Buy Airplane Tickets on the Tiket.com application; (3) Based on the T test conducted by the researcher. Advertising Exposure has a positive influence on the Decision to Buy Airplane Tickets on the Tiket.com Application, so Ha is accepted, Ho is rejected and Brand Awareness has a positive influence on the Decision to Buy Airplane Tickets on the Tiket.com Application, so Ha is accepted, Ho is rejected; (4) Based on the results of the F test that has been carried out by the researcher. Simultaneously shows that Advertising Exposure and Brand Awareness have a positive and significant influence on the Decision to Buy Airplane Tickets on the Tiket.com Application

Keywords: Format, Writing, Abstraction

\section{Abstraksi}

Penelitian ini bertujuan untuk menganalisis dan menjelaskan: (1) Pengaruh Terpaan Iklan Terhadap Keputusan Membeli Tiket Pesawat di Aplikasi Tiket.com; (2) Pengaruh Kesadaran Merek Terhadap Keputusan Membeli Tiket Pesawat di Aplikasi Tiket.com; (3) Pengaruh Terpaan Iklan dan Kesadaran Merek secara simultan Terhadap Keputusan Membeli Tiket Pesawat di Aplikasi Tiket.com. Penelitian ini menggunakan pendekatan kuantitatif. Pengumpulan data yang digunakan dalam penelitian ini adalah metode survei. Penyebaran kuesioner dilakukan dengan menggunakan google forms. Sampel yang digunakan berjumlah 100 responden merupakan pengguna aplikasi tiket.com ditetapkan menggunakan rumus slovin. Analisis data menggunakan program SPSS 25. Hasil dan kesimpulan dari 
penelitian ini menunjukan: (1) Berdasarkan hasil dari pengujian korelasi berganda, secara simultan antara variabel Terpaan Iklan dan Kesadaran Merek terhadap Keputusan Membeli terdapat hubungan yang erat dan kuat; (2) Berdasarkan hasil uji regresi yang sudah dilakukan oleh peneliti terdapat pengaruh positif. Jika Terpaan Iklan naik maka keputusan membeli Tiket Pesawat di Aplikasi Tiket.com akan naik pula, demikian juga dengan kenaikan Kesadaran Merek juga akan meningkatkan keputusan Membeli Tiket Pesawat di aplikasi Tiket.com; (3) Berdasarkan uji $\mathrm{T}$ yang dilakukan oleh peneliti. Terpaan Iklan memiliki pengaruh positif terhadap Keputusan Membeli Tiket Pesawat di Aplikasi Tiket.com, sehingga Ha diterima, Ho ditolak dan Kesadaran Merek memiliki pengaruh positif terhadap Keputusan Membeli Tiket Pesawat di Aplikasi Tiket.com, sehingga Ha diterima, Ho ditolak; (4) Berdasarkan hasil uji F yang telah dilakukan oleh peneliti. Secara simultan menunjukkan bahwa Terpaan Iklan dan Kesadaran Merek memiliki pengaruh positif dan signifikan terhadap Keputusan Membeli Tiket Pesawat di Aplikasi Tiket.com Kata Kunci: Terpaan Iklan, Kesadaran Merek, Keputusan Membeli

\section{PENDAHULUAN}

Konvergensi media terdapat di berbagai bidang seperti pendidikan, kesehatan, ekonomi, dan pariwisata. Hal tersebut terbukti dengan banyaknya perusahaan yang berkecimpung di dunia e-commerce. Menurut David Baum, "E-commerce is a dynamic set of technologies, applications, communities through electronic transactions and the electronic exchange of goods, service, and information". E-commerce merupakan satu set 
dinamis teknologi, aplikasi, dan proses bisnis yang menghubungkan perusahaan, konsumen, dan komunitas tertentu melalui transaksi elektronik dan perdagangan barang pelayanan, dan informasi yang dilakukan secara elektronik (Alfiah et al. 2015).

Hal tersebut membuktikan bahwa kecanggihan teknologi pada masa sekarang ini sangat mempermudah masyarakat, seperti munculnya beberapa aplikasi online. Salah satunya online travel agent, yang diketahui sebelum adanya teknologi, pemesanan tiket pesawat masih dilakukan secara offline hingga saat ini. Tetapi pembelian tiket pesawat secara offline dianggap kurang efisien, yang di mana masyarakat pada zaman ini ingin melakukan segala sesuatu dengan instan. Karena ketika membeli tiket pesawat secara langsung di loket maskapai penerbangan akan terjadinya antrean dan ketersediaan tiket yang tidak pasti, membuat adanya penurunan penjualan tiket pesawat secara offline. Oleh karena permasalahan di atas, banyak perusahaan travel agent yang memanfaatkan peluang ini untuk berkecimpung diperusahaan $e$ commerce, seperti salah satunya aplikasi tiket.com. Tiket.com merupakan perusahaan e-commerce yang bergerak di bidang online travel agent sejak Agustus 2011. Perusahaan ini membantu pengguna jasanya untuk mencari tiket pesawat, kereta api, event dan hotel yang tersedia via website maupun aplikasi. Tiket.com muncul untuk membantu masyarakat dalam membeli tiket pesawat UNIVERSITAS 17 AGUSTUS 1945 JAKARTA 
secara cepat dengan membeli online. Aplikasi tiket.com juga membantu masyarakat dalam pengecekan ketersedian tiket. Tiket.com terus mengembangkan aplikasinya, untuk membuat masyarakat merasa nyaman dalam menggunakan Aplikasi dari Tiket.com. Tiket.com juga terus membangun promosi dalam menggunakan iklan, supaya masyarakat mengetahui apa saja isi didalam aplikasi tiket.com dan cara menggunakan tiket.com.

Perusahaan yang bergerak di bidang online juga harus memasarkan produk atau jasanya secara online. Dengan adanya terobosan iklan dianggap paling efektif dan efisien untuk mengenalkan produk dan jasa kepada konsumen, sehingga dapat memengaruhi keputusan pembelian konsumen. Selain itu pentingnya juga konvergensi media untuk diterapkan dalam sebuah perusahaan. Menurut Deuze, konvergensi media harus dilihat sebagai "kerja sama dan kolaborasi" antara bentuk media yang sebelumnya dan yang ada sekarang”. Burnett dan Marshall menjelaskan konvergensi sebagai campuran media, telekomunikasi dan industri komputer atau dengan kata lain, sebagai proses mengaburkan batas-batas antara platform media yang berbeda dan menyatukan mereka dalam satu digital (Sediyaningsih 2018). Maka dari itu tiket.com memanfaatkan semua platform media, seperti televisi, instagram, dan youtube. mana jika orang terkena terpaan iklan yang dibangun oleh perusahaan secara terus menerus, maka orang kan menciptakan UNIVERSITAS 17 AGUSTUS 1945 JAKARTA 
sikap terhadap produk tersebut. Jika orang sudah menyukai produk tersebut mereka akan berpikir untuk memutuskan membeli produk tersebut. Seperti pada Teori Advertising Exposure Process menurut Aaker, Batra \& Myers, apabila audiens terkena terpaan iklan maka akan menciptakan sikap dan perasaan tertentu terhadap suatu produk yang kemudian menggerakkan audiens untuk mengkonsumsi produk tersebut (Norhabiba 2020).

Menurut Hermawan (2014:57) dalam jurnal (Ramadayanti 2019)), kesadaran merek adalah kemampuan dari seseorang calon pembeli (Potential Buyer) untuk mengenali (Recognize) atau mengingat (Recall) suatu merek yang merupakan bagian dari suatu kategori produk. Kemampuan konsumen untuk mengenal dan mengingat merek berperan besar dalam keputusan seseorang untuk membeli barang.

Begitu juga dengan tiket.com yang menerapkan kesadaran merek (Brand Awareness) di dalam strategi perusahaannya. Contohnya seperti logo tiket.com terlihat simpel dan memiliki perpaduan warna yang menarik sehingga masyarakat mudah mengingatnya. Tiket.com juga membuat sebuah slogan "mau ke mana? Semua ada tiketnya!" yang membuat masyarakat langsung sadar akan mereknya. Sehingga pentingnya kesadaran merek yang berpengaruh terhadap keputusan pembelian tiket pesawat di tiket.com. 
Maka dari itu, peneliti tertarik untuk meneliti yang baru dari berbagai faktor yang ada. Peneliti memilih faktor terapaan iklan, kesadaran merek dan keputusan pembelian apakah saling berkaitan dan memiliki pengaruh positif dalam sektor online travel agent. Peneliti dokus pada bagaimana pengaruh terpaan iklan dan kesadaran merek terhadap keputusan membeli tiket pesawat di aplikasi tiket.com( Oleh Pengguna Aplikasi Tiket.Com di Indonesia)

Penelitian mengenai terpaan iklan, kesadaran merek dan keputusan membeli ini tidak terlepas dari penelitian-penelitian yang telah dilakukan sebelumnya.

Peneltian dengan judul Pengaruh terpaan iklan nacific di instagram terhadap keputusan pembelian produk nacific pada followers akun @ nacificofficial.id. dilakukan oleh Didiek Tranggono, Ajeng Nidita Putri dan Juwito pada tahun 2020. Hasil penelitian menunjukkan bahwa terpaan iklan Nacific di Instagram memiliki pengaruh positif terhadap keputusan pembelian produk yang diiklankan. Sehingga, H1, H2 dan H3 diterima, yakni frekuensi, durasi dan intensitas memiliki pengaruh terhadap keputusan pembelian yang memiliki indikator; pilihan produk, pilihan merek, pilihan penyalur, jumlah pembelian, waktu pembelian dan metode pembayaran. Kebaruan dari penelitian ini adalah bahwa peneliti berfokus pada analisa variabel terpaan iklan 
dan kesadaran merek terhadap keputusan pembelian tiket pesawat diaplikasi tiket.com

Penelitian dengan judul Kesadaran Merek Pengaruhnya Pada Keputusan Pembelian Wisatawan Domestik dilakukan oleh Sopa Martina, dan L Hakim pada tahun 2018. Hasil penelitian menyimpulkan Pertama, tingkat kesadaran merek dan tingkat keputusan pembelian wisatawan domestik pada Sentra Rajut Binong Jati berada pada kategori sedang. Kedua, kesadaran merek berpengaruh positif dan signifikan terhadap keputusan pembelian. Kebaruan dari penelitian ini adalah bahwa peneliti berfokus pada analisa variabel terpaan iklan dan kesadaran merek terhadap keputusan pembelian tiket pesawat diaplikasi tiket.com

Penelitian dengan judul Analisis pengaruh kesadaran merek, harga, dan Promosi terhadap keputusan pembelian kartu Prabayar xl di kalangan mahasiswa (studi pada mahasiswa universitas diponegoro) dilakukan oleh Raihan Fakhrin Anggana, Idris pada tahun 2017. Hasil penelitian ini, merek, kesadaran, harga, dan promosi berpengaruh positif terhadap keputusan pembelian konsumen untuk XL layanan telekomunikasi prabayar mahasiswa Universitas Diponegoro. Variabel itu Digunakan dalam penelitian ini yang memiliki pengaruh terbesar terhadap keputusan pembelian produk XL pascabayar Promosi dan variabel yang paling kecil pengaruhnya terhadap produk XL pascabayar adalah merek kesadaran. 
Penelitian dengan judul Building Repurchase Intention and Purchase Decision: Brand Awareness and Brand Loyalty Analysis (Case Study Private Label Product in Alfamidi Tangerang). Hasil penelitian ini dapat disimpulkan Kesadaran Merek, Persepsi Kualitas, Kesadaran Merek, dan Loyalitas Merek secara bersama-sama berpengaruh signifikan terhadap niat membeli kembali. Hal ini menunjukkan bahwa telah terjadi kesadaran merek oleh konsumen terhadap produk private label yang dijual di gerai Alfamidi, persepsi persepsi kualitas pada pengalaman pembelian sebelumnya dapat menciptakan loyalitas terhadap merek yang dijualnya. Hal ini dapat berdampak positif bagi konsumen dalam mengevaluasi dan memilih untuk membeli private label di kemudian hari Kebaruan dari penelitian ini adalah bahwa peneliti berfokus pada analisa variabel terpaan iklan dan kesadaran merek terhadap keputusan pembelian tiket pesawat diaplikasi tiket.com.

Penelitian dengan judul Terpaan Iklan Digital, Word Of Mouth dan Komunikasi Pemasaran Interaktif pada Keputusan Pembelian Produk Perawatan Tubuh oleh Paramita Purnama, Rosita Anggraini, Arintowati Hartono, Irwansyah, Niken F. Ernungtyas, 2019. Hasil uji regresi menunjukkan secara statistik seluruh hipotesis memiliki pengaruh terhadap keputusan pembelian dengan tingkat kekuatan pengaruh yang berbeda-beda. Variabel terpaan iklan dan word of mouth. Kebaruan dari UNIVERSITAS 17 AGUSTUS 1945 JAKARTA 
penelitian ini adalah bahwa peneliti berfokus pada analisa variabel terpaan iklan dan kesadaran merek terhadap keputusan pembelian tiket pesawat diaplikasi tiket.com

\section{METODOLOGI PENELITIAN}

\section{A. Jenis Penelitian}

Dalam penelitian ini menggunakan metode kuantitatif yang berisi data-data statistik yang dapat diukur, diolah, dan dihitung. Sugiyono (2016:35-38).

\section{B. Teknik Pengumpulan Data}

Teknik pengumpulan data yang digunakan dalam penelitian ini, yaitu observasi dan kuesioner, Data diperoleh dengan beberapa metode, yaitu observasi dan kuesioner. Observasi merupakan suatu pengamatan dengan menggunakan indra penglihatan. Dalam kegiatan pengamatan, observer (pengamat) belum mengajukan pertanyaan-pertanyaan khusus yang terkait dengan masalah penelitian.

Kuesioner merupakan teknik pengumpulan data yang dilakukan dengan cara memberi seperangkat pertanyaan atau pernyataan tertulis kepada responden untuk dijawabnya (Sugiyono, 2010). Kuesioner merupakan teknik pengumpulan data yang efisien bila peneliti tahu dengan pasti variabel yang akan diukur dan tahu apa yang bisa diharapkan oleh responden. Kuesioner yang dipakai menggunakan skala likert, yaitu mengukur UNIVERSITAS 17 AGUSTUS 1945 JAKARTA 
sikap, pendapat, dan persepsi seseorang atau sekelompok orang tentang fenomena sosial. Skala yang berisi lima tingkat preferensi jawaban dengan pilihan jawaban dengan tabel sebagai berikut: Sangat Setuju $(\mathrm{SS})=5$

Setuju $(\mathrm{S})=4$

Netral $(\mathrm{N})=3$

Tidak Setuju $($ TS $)=2$

Sangat Tidak Setuju $($ STS $)=1$

\section{Teknik Analisa Data}

Data yang diperoleh dari hasil kuesioner akan diuji dengan metode analisis Statistical Product and Service Solution (SPSS) meliputi Uji validitas, Uji Reliabilitas, Uji Normalitas, Uji Multikolinearitas, Uji Heteroskedastisitas, Analisis Korelasi, Analisis Korelasi Berganda, Analisis regresi Berganda, Uji hipotesis, Uji Parsial (Uji T), Uji Signifikasi Simultasn (Uji F)

\section{PEMBAHASAN}

\section{A. Hasil Pretest Uji Validitas}

Dasar pengambilan keputusan pada uji validitas adalah :

1. Jika nilai $\mathrm{r}_{\text {hitung }}>\mathrm{rt}_{\mathrm{abel}}$, maka item pertanyaan atau pertanyaan dalam angket berkolerasi signifikan terhadap skor total (artinya item angket dinyatakan valid). 
2. Jika nilai $\mathrm{r}_{\text {hitung }}<\mathrm{rt}_{\text {abel }}$, makan item pertanyaan atau pertanyaan dalam angket tidak berkorelasi signifikan terhadap skor total (artinya item angket dinyatakan tidak valid) (Widyanto, 2010).

Berikut hasil pengujian validitas variabel terpaan iklan, kesadaraan merek dan keputusan pembelian:

Tabel1 Hasil Uji Validitas Variabel Terpaan Iklan

\begin{tabular}{|l|c|c|r|}
\hline No. Item & rhitung $_{\text {rabel }}$ & \multicolumn{1}{c|}{ Keterangan } \\
\hline TI_1 & 0,783 & 0,361 & Valid \\
\hline TI_2 & 0,817 & 0,361 & Valid \\
\hline TI_3 & $\mathbf{0 , 2 0 6}$ & $\mathbf{0 , 3 6 1}$ & Tidak Valid \\
\hline TI_4 & 0,599 & 0,361 & Valid \\
\hline TI_5 & 0,643 & 0,361 & Valid \\
\hline TI_6 & 0,827 & 0,361 & Valid \\
\hline TI_7 & 0,732 & 0,361 & Valid \\
\hline TI_8 & 0,776 & 0,361 & Valid \\
\hline
\end{tabular}

Sumber data : Hasil Olah Data SPSS 25, n=100 (2021)

Berdasarkan hasil olah data menggunakan SPSS versi 25 untuk variabel Terpaan Iklan (X1), terlihat dari jumlah 8 pertanyaan kuesioner yang diberikan kepada responden saat pretest, poin pertanyaan TI_3 tidak valid, karena nilai $\mathrm{r}_{\text {hitung }}$ lebih kecil dari nilai $r_{\text {tabel }}$ pada taraf signifikansi 0,05 untuk $n=30$. Maka dari itu hanya tersisa 7 pertanyaan kuisioner yang valid yang akan dibagikan kepada sampel responden. 
Tabel 2 Hasil Uji Validitas Variabel Kesadaran Merek

\begin{tabular}{|l|r|r|r|}
\hline \multicolumn{1}{|c|}{ No. Item } & \multicolumn{1}{c|}{$\mathbf{r}_{\text {hitung }}$} & \multicolumn{1}{c|}{$\mathbf{r}_{\text {tabel }}$} & Keterangan \\
\hline KM_1 & 0,549 & 0,361 & Valid \\
\hline KM_2 & 0,563 & 0,361 & Valid \\
\hline KM_3 & 0,504 & 0,361 & Valid \\
\hline KM_4 & 0.669 & 0,361 & Valid \\
\hline KM_5 & 0,750 & 0,361 & Valid \\
\hline KM_6 & 0,538 & 0,361 & Valid \\
\hline KM_7 & 0,381 & 0,361 & Valid \\
\hline KM_8 & 0,413 & 0,361 & Valid \\
\hline KM_9 & 0,582 & 0,361 & Valid \\
\hline KM_10 & 0,454 & 0,361 & Valid \\
\hline
\end{tabular}

Sumber data : Hasil Olah Data SPSS 25, n=100 (2021)

Berdasarkan hasil olah data menggunakan SPSS versi 25 untuk variabel Kesadaran Merek (X2), terlihat dari jumlah 10 pertanyaan kuesioner yang diberikan kepada responden saat

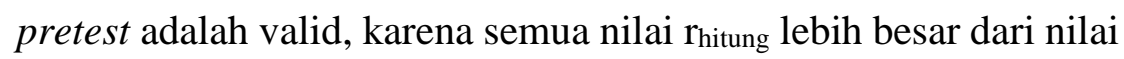
$\mathrm{r}_{\text {tabel }}$ pada taraf signifikansi 0,05 untuk $\mathrm{n}=30$. Maka dari itu seluruh pertanyaan kuesioner pada variabel X2 ini akan dibagikan kepada sampel responden. 
Tabel 3 Hasil Uji Validitas Variabel Keputusan Pembelian

\begin{tabular}{|c|c|c|c|}
\hline No. Item & rhitung & $\mathbf{r}_{\text {tabel }}$ & Keterangan \\
\hline KP_1 & 0,801 & 0,361 & Valid \\
\hline KP_2 & 0,799 & 0,361 & Valid \\
\hline KP_3 & 0,720 & 0,361 & Valid \\
\hline KP_4 & 0,796 & 0,361 & Valid \\
\hline KP_5 & 0,700 & 0,361 & Valid \\
\hline KP_6 & 0,707 & 0,361 & Valid \\
\hline KP_7 & 0,888 & 0,361 & Valid \\
\hline KP_8 & 0,762 & 0,361 & Valid \\
\hline KP_9 & 0,778 & 0,361 & Valid \\
\hline KP_10 & 0,829 & 0,361 & Valid \\
\hline KP_11 & 0,897 & 0,361 & Valid \\
\hline KP_12 & 0,786 & 0,361 & Valid \\
\hline KP_13 & 0,846 & 0,361 & Valid \\
\hline KP_14 & 0,803 & 0,361 & Valid \\
\hline KP_15 & 0,765 & 0,361 & Valid \\
\hline KP_16 & 0,830 & 0,361 & Valid \\
\hline KP_17 & 0,496 & 0,361 & Valid \\
\hline KP_18 & 0,700 & 0,361 & Valid \\
\hline
\end{tabular}

Sumber data: Hasil Olah Data SPSS 25, n=100 (2021)

Berdasarkan hasil olah data menggunakan SPSS versi 25 untuk variabel Keputusan Pemebelian (Y), terlihat dari jumlah 18 pertanyaan kuesioner yang diberikan kepada responden saat pretest adalah valid, karena semua nilai $r$ hitung lebih besar dari nilai $r$ tabel pada taraf signifikansi 0,05 untuk $n=30$. Maka dari itu seluruh pertanyaan kuesioner pada variabel $\mathrm{Y}$ ini akan dibagikan kepada sampel responden. 


\section{B. Hasil Uji Validitas}

Dasar pengambilan keputusan pada uji validitas adalah :

1. Jika nilai $\mathrm{r}_{\text {hitung }}>\mathrm{rt}_{\mathrm{abel}}$, maka item pertanyaan atau pertanyaan dalam angket berkolerasi signifikan terhadap skor total (artinya item angket dinyatakan valid).

2. Jika nilai $\mathrm{r}_{\text {hitung }}<\mathrm{rt}_{\text {abel}}$, makan item pertanyaan atau pertanyaan dalam angket tidak berkorelasi signifikan terhadap skor total (artinya item angket dinyatakan tidak valid) (Widyanto, 2010).

Berikut hasil pengujian validitas variabel terpaan iklan, kesadaraan merek dan keputusan pembelian:

Tabel 4 Hasil Uji Validitas Variabel Terpaan Iklan

\begin{tabular}{|l|c|c|r|}
\hline No. Item & rhitung & rtabel & Keterangan \\
\hline TI_1 & 0,779 & 0,361 & Valid \\
\hline TI_2 & 0,813 & 0,361 & Valid \\
\hline TI_3 & 0,664 & 0,361 & Valid \\
\hline TI_4 & 0,672 & 0,361 & Valid \\
\hline TI_5 & 0,861 & 0,361 & Valid \\
\hline TI_6 & 0,762 & 0,361 & Valid \\
\hline TI_7 & 0,789 & 0,361 & Valid \\
\hline
\end{tabular}

Sumber data : Hasil Olah Data SPSS 25, n=100 (2021) 
Berdasarkan hasil olah data menggunakan SPSS versi 25 untuk variabel Terpaan Iklan (X1), terlihat dari jumlah 7 pertanyaan kuesioner yang diberikan kepada responden adalah valid, karena semua nilai $r_{\text {hitung }}$ lebih besar dari nilai $r_{\text {tabel }}$ pada taraf signifikansi 0,05 untuk $\mathrm{n}=30$.

Tabel 5 Hasil Uji Validitas Variabel Kesadaran Merek

\begin{tabular}{|l|r|r|r|}
\hline \multicolumn{1}{|c|}{ No. Item } & \multicolumn{1}{c|}{ r hitung } & \multicolumn{1}{c|}{ rtabel } & Keterangan \\
\hline KM_1 & 0,549 & 0,361 & Valid \\
\hline KM_2 & 0,563 & 0,361 & Valid \\
\hline KM_3 & 0,504 & 0,361 & Valid \\
\hline KM_4 & 0.669 & 0,361 & Valid \\
\hline KM_5 & 0,750 & 0,361 & Valid \\
\hline KM_6 & 0,538 & 0,361 & Valid \\
\hline KM_7 & 0,381 & 0,361 & Valid \\
\hline KM_8 & 0,413 & 0,361 & Valid \\
\hline KM_9 & 0,582 & 0,361 & Valid \\
\hline KM_10 & 0,454 & 0,361 & Valid \\
\hline
\end{tabular}

Sumber data : Hasil Olah Data SPSS 25, n=100 (2021)

Berdasarkan hasil olah data menggunakan SPSS versi 25 untuk variabel Kesadaran Merek (X2), terlihat dari jumlah 10 pertanyaan kuesioner yang diberikan kepada responden adalah valid, karena semua nilai $r_{h i t u n g}$ lebih besar dari nilai $r_{\text {tabel }}$ pada taraf signifikansi 0,05 untuk $\mathrm{n}=30$. 
Tabel 6 Hasil Uji Validitas Variabel Keputusan Membeli

\begin{tabular}{|l|r|r|r|}
\hline \multicolumn{1}{|c|}{ No. Item } & \multicolumn{1}{c|}{ r hitung } & \multicolumn{1}{c|}{ r tabel } & Keterangan \\
\hline KP_1 & 0,801 & 0,361 & Valid \\
\hline KP_2 & 0,799 & 0,361 & Valid \\
\hline KP_3 & 0,720 & 0,361 & Valid \\
\hline KP_4 & 0,796 & 0,361 & Valid \\
\hline KP_5 & 0,700 & 0,361 & Valid \\
\hline KP_6 & 0,707 & 0,361 & Valid \\
\hline KP_7 & 0,888 & 0,361 & Valid \\
\hline KP_8 & 0,762 & 0,361 & Valid \\
\hline KP_9 & 0,778 & 0,361 & Valid \\
\hline KP_10 & 0,829 & 0,361 & Valid \\
\hline KP_11 & 0,897 & 0,361 & Valid \\
\hline KP_12 & 0,786 & 0,361 & Valid \\
\hline KP_13 & 0,846 & 0,361 & Valid \\
\hline KP_14 & 0,803 & 0,361 & Valid \\
\hline KP_15 & 0,765 & 0,361 & Valid \\
\hline KP_16 & 0,830 & 0,361 & Valid \\
\hline KP_17 & 0,496 & 0,361 & Valid \\
\hline KP_18 & 0,700 & 0,361 & Valid \\
\hline Su_ & 0,16 D & SPS & n \\
\hline
\end{tabular}

Sumber data : Hasil Olah Data SPSS 25, n=100 (2021)

Berdasarkan hasil olah data menggunakan SPSS versi 25 untuk variabel Keputusan Membeli (Y), terlihat dari jumlah 18 pertanyaan kuesioner yang diberikan kepada responden saat adalah valid, karena semua nilai $r$ hitung lebih besar dari nilai $r$ tabel pada taraf signifikansi 0,05 untuk $\mathrm{n}=30$.

\section{Hasil Uji Reliabilitas}

Realibitas menurut Sarjono (2011) adalah mengukur konsistensi dari tidaknya jawaban setiap responden terhadap itemUNIVERSITAS 17 AGUSTUS 1945 JAKARTA 
item pernyataan yang berada di dalam kuesioner yang sudah disebarkan itu dapat terpercaya atau reliabele. Suatu variabel dikatakan reliabel jika memberikan nilai Cronbach Alpha (a) > 0,60. (Ghozali, 2013). Berikut hasil pengujian reliabilitas variabel Terpaan Iklan, Kesadaran Merek dan Keputusan Membeli:

Tabel 7 Hasil Uji Reliabilitas Variabel Terpaan Iklan

\begin{tabular}{|c|c|}
\hline \multicolumn{2}{|c|}{ Reliability Statistics } \\
\hline Cronbach's Alpha & N of Items \\
\hline 0,871 & 7 \\
\hline
\end{tabular}

Sumber data : Hasil Olah Data SPSS 25, n=100 (2021)

Berdasarkan hasil perhitungan uji reliabilitas menggunakan SPSS versi 25 untuk variabel terpaan iklan (X1), diperoleh koefisien reabilitas Cronbach Alpha sebesar 0,871. Dengan hasil tersebut, maka dapat dikatakan bahwa variabel tersebut adalah reliabel karena memberikan nilai Cronbach Alpha (a) $>0,60$.

Tabel 8 Uji Reliabilitas Variabel Kesadaran Merek

\begin{tabular}{|r|l|}
\hline \multicolumn{2}{|c|}{ Reliability Statistics } \\
\hline Cronbach's Alpha & N of Items \\
\hline 0,729 & \\
\hline
\end{tabular}

Sumber data : Hasil Olah Data SPSS 25, n=100 (2021)

Hasil perhitungan uji reliabilitas menggunakan SPSS versi 25 untuk variabel Kesadaran merek (X2), diperoleh koefisien reabilitas Cronbach Alpha sebesar 0,729. Dengan hasil tersebut, UNIVERSITAS 17 AGUSTUS 1945 JAKARTA 
maka dapat dikatakan bahwa variabel tersebut adalah reliabel karena memberikan nilai Cronbach Alpha (a) >0,60.

Tabel 9 Hasil Uji Reliabilitas Variabel Keputusan Membeli

\begin{tabular}{|r|c|}
\hline \multicolumn{2}{|c|}{ Reliability Statistics } \\
\hline Cronbach's Alpha & N of Items \\
\hline 0,958 & 18 \\
\hline
\end{tabular}

Sumber data : Hasil Olah Data SPSS 25, n=100 (2021)

Hasil perhitungan uji reliabilitas menggunakan SPSS versi 25 untuk variabel Keputusan Membeli (Y), diperoleh koefisien reabilitas Cronbach Alpha sebesar 0,958. Dengan hasil tersebut, maka dapat dikatakan bahwa variabel tersebut adalah reliabel karena memberikan nilai Cronbach Alpha (a) > 0,60.

\section{Uji Normalitas}

Gambar 6 Uji Normalitas

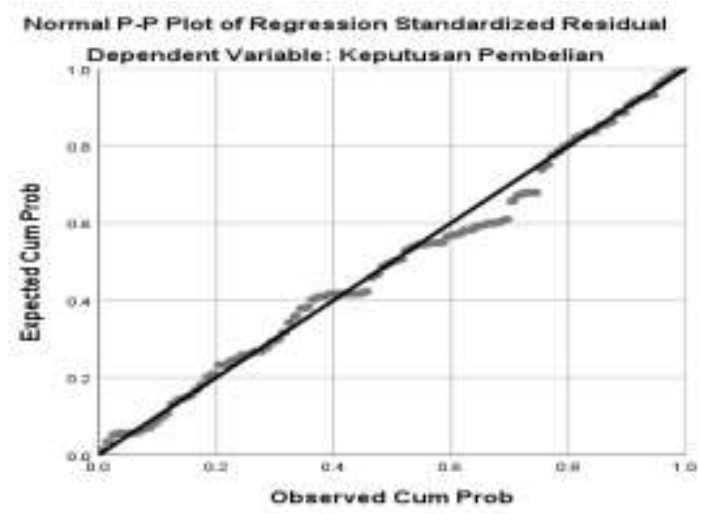

Sumber data : Hasil Olah Data SPSS 25, n=100 (2021) 
Dapat dilihat dari gambar 4.7 bahwa titik menyebar disekitar dekat sumbu diagonal dan mengikuti garis diagonal, hal ini membuktikan bahwa data penelitian yang berasal dari populasi berdistribusi normal. Maka model regresi dinyatakan memenuhi asumsi normalitas.

\section{E. Uji Multikolinearitas}

Uji multikolinearitas dilakukan untuk mengetahui ada atau tidaknya korelasi antar variabel independen dalam model regresi.

Tabel 10 Hasil Uji Multikolinearitas

\begin{tabular}{|ll|l|l|}
\hline \multirow{2}{*}{ Model } & \multicolumn{2}{|c|}{ Collinearity Statistics } \\
\cline { 2 - 3 } $\mathbf{1}$ & Tolerance & VIF \\
\cline { 2 - 3 } & Terpaan Iklan & .425 & \\
\hline \multicolumn{2}{|c|}{ Kesadaran Merek } & .425 & 2.352 \\
\hline
\end{tabular}

a. Dependent Variabel : Keputusan Membeli

Sumber data : Hasil Olah Data SPSS 25, n=100 (2021)

Dapat diliaht dari tabel 4.45 menunjukkan bahwa keseluruhan nilai tolerance yang dihasilkan dalam penelitian ini $0.425>0.10$, dan nilai VIF $2.352<10.00$. Dapat disimpulkan bahwa variabel independen tidak mengalami multikolinieritas dan memenuhi prasyarat uji asumsi klasik. 


\section{F. Uji Heteroskedastisitas}

Gambar 7 Hasil Uji Heteroskedas

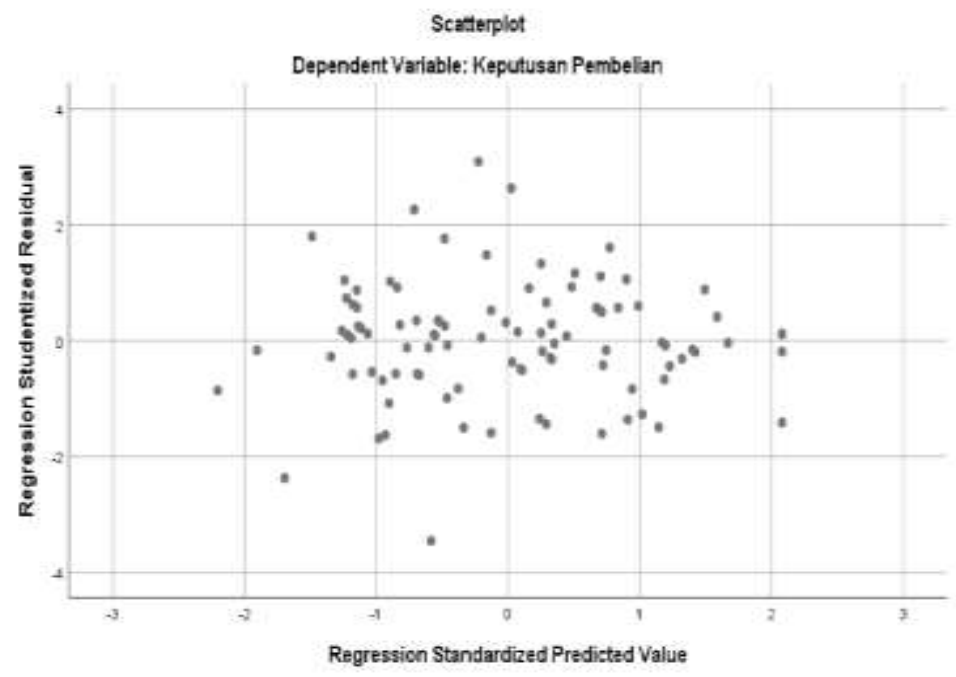

Sumber data : Hasil Olah Data SPSS 25, n=100 (2021)

Berdasarkan gambar 4.8 uji heteroskeditastisitas menunjukan tidak terjadi gejala heteroskeditastisitas, hal ini terlihat dari:

1. Titik tidak menyebar di atas di bawah angka nol;

2. Titik-titik data tidak menyebar hanya diatas atau di bawah angka nol saja;

3. Penyebaran titik-titik data tidak berpola tertentu. 


\section{G. Uji Korelasi}

Tabel 11 Hasil Uji Korelasi Sedeharna (X1 - Y dan X2 -Y)

\begin{tabular}{|c|c|c|c|c|}
\hline \multicolumn{5}{|c|}{ Correlations } \\
\hline & & $\begin{array}{l}\text { Terpaa } \\
\text { n Iklan }\end{array}$ & $\begin{array}{l}\text { Kesadara } \\
\text { n Merek }\end{array}$ & $\begin{array}{c}\text { Keputusa } \\
\text { n } \\
\text { Pembelia } \\
n\end{array}$ \\
\hline \multirow[t]{3}{*}{$\begin{array}{l}\text { Terpaan } \\
\text { Iklan }\end{array}$} & $\begin{array}{l}\text { Pearson } \\
\text { Correlation }\end{array}$ & 1 & $.691^{* *}$ & $719^{* * *}$ \\
\hline & $\begin{array}{l}\text { Sig. } \\
\text { tailed) }\end{array}$ & & .000 & .000 \\
\hline & $\mathrm{N}$ & 100 & 100 & 100 \\
\hline \multirow{3}{*}{$\begin{array}{l}\text { Kesadar } \\
\text { an } \\
\text { Merek }\end{array}$} & $\begin{array}{l}\text { Pearson } \\
\text { Correlation }\end{array}$ & $.691^{* *}$ & 1 & $.625^{* *}$ \\
\hline & $\begin{array}{l}\text { Sig. } \\
\text { tailed) }\end{array}$ & .000 & & .000 \\
\hline & $\mathrm{N}$ & 100 & 100 & 100 \\
\hline \multirow{3}{*}{$\begin{array}{l}\text { Keputus } \\
\text { an } \\
\text { Membeli }\end{array}$} & $\begin{array}{l}\text { Pearson } \\
\text { Correlation }\end{array}$ & $.719^{* *}$ & $.625^{* *}$ & 1 \\
\hline & $\begin{array}{l}\text { Sig. } \\
\text { tailed) }\end{array}$ & .000 & .000 & \\
\hline & $\mathrm{N}$ & 100 & 100 & 100 \\
\hline
\end{tabular}

Sumber data : Hasil Olah Data SPSS 25, n=100 (2021)

Dari tabel 4.46 hasil uji korelasi antara variabel Terpaan

Iklan X1 dan Y, dapat disimpulkan menjadi 3 poin :

1. Terdapat hubungan antara variabel $\mathrm{X} 1$ dan $\mathrm{Y}$, hal ini dapat dilihat dari nilai Sig yang menunjukan nilai 0,000 dimana nilai tersebut lebih kecil dari 0,05 . 
2. Hubungan antara 2 variabel tersebut adalah hubungan yang positif, yang artinya apabila terdapat peningkatan pada variabel Terpaan Iklan Tiket.com maka keputusan membeli tiket peswat di aplikasi tiket.com juga akan mengalami peningkatan.

3. Nilai koefisien korelasi Pearson Correlation sebesar 0,719. Tingkat hubungan antara kedua variabel termasuk dalam korelasi kuat, karena berada dalam interval 0,60-0,799 dengan tingkat hubungan kuat.

Dari tabel 4.42 hasil uji korelasi antara variabel Kesadaran Merek (X2) dan Y, dapat disimpulkan menjadi 3 poin : 1. Terdapat hubungan antara variabel $\mathrm{X} 2$ dan $\mathrm{Y}$, hal ini dapat dilihat dari nilai Sig yang menunjukan nilai 0,000 dimana nilai tersebut lebih kecil dari 0,05.

2. Hubungan antara 2 variabel tersebut adalah hubungan yang positif, yang artinya apabila terdapat peningkatan pada variabel Kesadaran Merek Tiket.com maka keputusan membeli tiket peswat di aplikasi tiket.com juga akan mengalami peningkatan.

Nilai koefisien korelasi Pearson Correlation sebesar 0,625. Tingkat hubungan antara kedua variabel termasuk dalam korelasi kuat, karena berada dalam interval 0,60-0,799 dengan tingkat hubungan kuat 
PROMEDIA (PUBLIC RELATION DAN MEDIA KOMUNIKASI) ISSN 2460-9633,

Volume Ke-7 No. 2, 2021, Kesuma,dkk Terpaan Iklan, hal 285 - hal 320

Tabel 12 Hasil Uji Korelasi Berganda (X1,X2 - Y)

\begin{tabular}{|c|c|c|c|c|c|c|c|c|c|}
\hline \multicolumn{10}{|c|}{ Model Summary } \\
\hline Model & $\mathrm{R}$ & $\begin{array}{c}\mathrm{R} \\
\text { Square }\end{array}$ & $\begin{array}{c}\text { AdjustedR } \\
\text { Square }\end{array}$ & \begin{tabular}{c} 
Std. \\
Error of \\
the \\
\cline { 5 - 9 }
\end{tabular} & & & & \multicolumn{5}{|c|}{ Change Statistics } \\
\cline { 5 - 9 } & & & $\begin{array}{c}\mathrm{R} \\
\text { Square } \\
\text { Change }\end{array}$ & $\begin{array}{c}\mathrm{F} \\
\text { Change }\end{array}$ & df1 & df2 & $\begin{array}{c}\text { Sig. F } \\
\text { Change }\end{array}$ \\
\hline 1 & $.717^{\mathrm{a}}$ & .514 & .504 & 8.10041 & .514 & 51.318 & 2 & 97 \\
\hline
\end{tabular}

a. Predictors: (Constant), Kesadaran Merek, Terpaan Iklan

b. Dependent Variable: Keputusan Membeli

Sumber data : Hasil Olah Data SPSS 25, n=100 (2021)

Berdasarkan tabel 12 diperoleh nilai koefisien (R) sebesar 0,717. Koefisien korelasi tersebut memiliki hubungan yang positif dengan tingkat hubungan yang termasuk dalam korelasi kuat, karena berada dalam interval 0,60-0,799 dengan tingkat hubungan yang kuat. Sehingga terdapat hubungan positif yang erat antara Terpaan Iklan dan Kesadaran Merek terhadap Keputusan membeli tiket pesawat di aplikasi tiket.com.

\section{H. Uji Regresi Berganda}

Tabel 13 Hasil Uji Regresi (X1,X2 - Y)

\begin{tabular}{|c|c|c|c|c|c|c|}
\hline \multicolumn{7}{|c|}{ Coefficients $^{\mathrm{a}}$} \\
\hline & & \multicolumn{2}{|c|}{ Unstandardized Coefficients } & $\begin{array}{l}\text { Standardized } \\
\text { Coefficients }\end{array}$ & \multirow[b]{2}{*}{$\mathrm{t}$} & \multirow[b]{2}{*}{ Sig. } \\
\hline \multicolumn{2}{|c|}{ Model } & $\mathrm{B}$ & Std. Error & Beta & & \\
\hline \multirow[t]{3}{*}{1} & (Constant) & 28.240 & 4.550 & & 6.206 & .000 \\
\hline & Terpaan Iklan & 1.055 & .213 & .497 & 4.955 & .000 \\
\hline & Kesadaran Merek & .486 & .179 & .273 & 2.718 & .008 \\
\hline
\end{tabular}

a. Dependent Variable: Keputusan Membeli

Sumber data : Hasil Olah Data SPSS 25, n=100 (2021) 


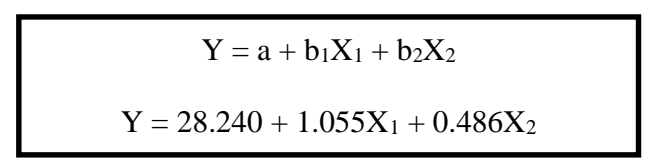

Hasil dari tabel 13 terlihat jika variabel terpaan iklan tiket.com dianggap konstan, maka nilai keputusan membeli tiket pesawat di aplikasi tiket.com sebesar 28.240 satuan.

Apabila nilai terpaan iklan tiket.com meningkat satu-satuan dan kesadaran merek adalah konstan, maka nilai keputusan membeli tiket pesawat di aplikasi tiket.com akan meningkat 1,055 satuan. Apabila nilai Kesadaran merek tiket.com meningkat satusatuan dan nilai Terpaan iklan adalah konstan, maka nilai keputusan membeli tiket pesawat di aplikasi tiket.com akan meningkat 0,486 satuan.

\section{Uji T}

Tabel 14 Hasil Uji T

\begin{tabular}{|l|l|r|r|r|r|r|}
\hline \multicolumn{7}{|c|}{ Coefficients $^{\mathbf{a}}$} \\
\hline \multirow{2}{*}{ Model } & \multicolumn{2}{|c|}{$\begin{array}{c}\text { Standardized } \\
\text { Coefficients }\end{array}$} & & \\
\hline 1 & Unstandardized Coefficients & Std. Error & Beta & t & Sig. \\
\cline { 2 - 8 } & B Constant) & 28.240 & 4.550 & & 6.206 & .000 \\
\cline { 2 - 8 } & Terpaan Iklan & 1.055 & .213 & .497 & 4.955 & .000 \\
\cline { 2 - 8 } & Kesadaran Merek & .486 & .179 & .273 & 2.718 & .008 \\
\hline
\end{tabular}

a. Dependent Variable: Keputusan membeli

Sumber data : Hasil Olah Data SPSS 25, n=100 (2021)

Nilai tabel $=\mathrm{t}(\mathrm{a} / 2 ; \mathrm{n}-\mathrm{k}-1)=\mathrm{t}(0.05 / 2 ; 100-2-1)=\mathrm{t}(0.025 ; 97)=1.98472$ 
Berdasarkan Tabel 14 dengan mengamati baris, kolom $t$ dan sig. Berikut penjelasannnya:

\section{Pengaruh Variabel Terpaan Iklan Terhadap Keputusan}

\section{Membeli Tiket Pesawat di Aplikasi Tiket.com $\left(\mathrm{H}_{1}\right)$}

Variabel terpaan iklan (X1) berpengaruh positif dan signifikan terhadap keputusan membeli tiket pesawat di aplikasi tiket.com. Hal ini dilihat dari signifikan terpaan iklan (X1) $0,000<0,05$ dan nilai $t_{\text {hitung }}$ lebih besar dari $t_{\text {tabel }}(4.955>$ 1.98472), Maka dari itu $H_{o}$ ditolak dan $H_{a}$ diterima. Sehingga hipotesis terdapat pengaruh terpaan iklan terhadap keputusan membeli tiket pesawat di aplikasi tiket.com diterima.

\section{Pengaruh Variabel Kesadaran Merek Terhadap Keputusan}

\section{Membeli Tiket Pesawat di Aplikasi Tiket.com ( $\left.\mathrm{H}_{1}\right)$}

Variabel Kesadaran merek (X2) berpengaruh positif dan signifikan terhadap keputusan membeli tiket pesawat di aplikasi tiket.com. Hal ini dilihat dari signifikan terpaan iklan (X2) $0,008<0,05$ dan nilai $t_{\text {hitung }}$ lebih besar dari $t_{\text {tabel }}(2.718>$ 1.98472), Maka dari itu Ho ditolak dan Ha diterima. Sehingga hipotesis terdapat pengaruh kesadaran merek terhadap keputusan membeli tiket pesawat di aplikasi tiket.com diterima. 


\section{J. Uji F}

Tabel 15 Hasil Uji F

\begin{tabular}{|c|c|c|c|c|c|c|}
\hline \multicolumn{7}{|c|}{ ANOVA $^{\mathrm{a}}$} \\
\hline \multicolumn{2}{|c|}{ Model } & Sum of Squares & $\mathrm{df}$ & Mean Square & $\mathrm{F}$ & Sig. \\
\hline \multirow[t]{3}{*}{1} & Regression & 6734.625 & 2 & 3367.312 & 51.318 & $.000^{\mathrm{b}}$ \\
\hline & Residual & 6364.815 & 97 & 65.617 & & \\
\hline & Total & 13099.440 & 99 & & & \\
\hline
\end{tabular}

a. Dependent Variable: Keputusan Membeli

b. Predictors: (Constant), Kesadaran Merek, Terpaan Iklan

Sumber data : Hasil Olah Data SPSS 25, n=100 (2021)

$$
\mathrm{F}_{\text {tabel }}=\mathrm{f}(\mathrm{k} ; \mathrm{n}-\mathrm{k})=(2 ; 100-2)=(2 ; 98)=3,09
$$

Berdasarkan hasil pengujian tabel 4.50 menunjukkan nilai $F_{\text {hitung }}$ sebesar 51.318 dengan nilai $F_{\text {tabel }}$ adalah 3.09 sehingga nilai $F_{\text {hitung }}>F_{\text {tabel }}$ atau $51.318>3.09$, dan tingkat signifikan $0.000<$ 0.05 maka Ho ditolak dan Ha diterima. Dengan demikian peneliti menyimpulkan bahwa terdapat pengaruh antara terpaan iklan dan kesadaran merek terhadap keputusan membeli tiket pesawat di aplikasi tiket.com.

Penelitian yang berjudul "Pengaruh Terpaan Iklan Dan Kesadaran Merek Terhadap Keputusan Membeli Tiket Pesawat di Aplikasi Tiket.Com (Oleh Pengguna Aplikasi Tiket.Com di Indonesia)" total responden yang berpartisipasi adalah sejumlah 100 orang, sesuai dengan jumlah hasil perhitungan sampel yang sudah ditetapkan. Responden yang terlibat dalam penelitian ini sebagian besar adalah responden wanita sebanyak 65 orang dengan UNIVERSITAS 17 AGUSTUS 1945 JAKARTA 
persentase $65 \%$. Sedangkan laki-laki terdiri dari 35 orang dengan presentase $35 \%$. Usia responden didominasi dengan usia 18 - 22 tahun dengan jumlah 72 orang atau $72 \%$. Responden yang mengisi pekerjaan saat ini lebih banyak mahasiswa dengan presentase $51 \%$ dan karyawan dengan presentase 38\%. responden yang menggunakan aplikasi tiket.com berjumlah 100 responden dengan presentase $100 \%$. responden yang sering melihat iklan tiket.com berjumlah 100 responden dengan presentase $100 \%$.

Berdasarkan penelitian yang telah dilakukan oleh penliti, peneliti menggunakan SPSS versi 25 untuk melakukan hasil olah data pengujian dalam penelitian ini. Peneliti melakukan uji korelasi, uji korelasi dilakukan antara variabel X1 dan $\mathrm{Y}$, variabel $\mathrm{X} 2$ dan $\mathrm{Y}$, dan variabel X1, X2, dan Y. Hasil yang didapatkan dari uji korelasi antara variabel Terpaan Iklan (X1) dan Keputusan Membeli (Y) adalah sebesar 0.719 yang artinya bahwa tingkat hubungan antara kedua variabel termasuk dalam kategori kuat dalam uji korelasi dengan interval 0,60-0,799.

Sedangkan hasil uji korelasi antara variabel Kesadaran Merek (X2) dan Keputusan Membeli adalah sebesar 0.625 yang artinya bahwa tingkat hubungan antara kedua variabel termasuk dalam kategori kuat dalam uji korelasi dengan interval 0,60-0,799. Untuk uji korelasi antara variabel $\mathrm{X} 1, \mathrm{X} 2$ dan $\mathrm{Y}$ adalah sebesar 0.717 yang artinya bahwa tingkat hubungan antara kedua variabel 
termasuk dalam kategori kuat dalam uji korelasi dengan interval 0,60-0,799.

Peneliti juga melakukan uji regresi berganda dengan SPSS versi 25 dan didapatkan hasil bahwa variabel Terpaan Iklan (X1) dan Kesadaran Merek (X2) Terhadap Keputusan Membeli Tiket Pesawat di Aplikasi Tiket.com (Y) memiliki nilai positif, tanda yang positif menyatakan arah hubungan yang searah dimana kenaikan atau penurunan variabel independen (X1 dan X2) akan mengakibatkan kenaikan atau penurunan juga pada variabel dependen (Y). Hasil uji regresi berganda digambarkan dengan persamaan $\mathrm{Y}=28.240+1.055 \mathrm{X} 1+0.486 \mathrm{X} 2$.

Selanjutnya peneliti melakukan uji hipotesis, uji hipotesis terdiri dari uji parsial (uji t) dan uji signifikansi simultan (uji F). Uji t yang dilakukan antara variabel Terpaan Iklan (X1) dan Keputusan Membeli (Y) didapatkan sebesar 4.955 dan nilai signifikasni 0,000. Dari hasil ini dapat diartikan bahwa terdapat pengaruh antara terpaan iklan terhadap keputusan pembelian tiket pesawat di aplikasi tiket.com.

Sedangkan uji t untuk variabel Kesadaran Merek (X2) dan Keputusan Membeli (Y) adalah sebesar 2.718 dan nilai signifikansi 0,008. Dari hasil ini dapat diartikan bahwa terdapat pengaruh antara kesadaran merek terhadap keputusan Membeli tiket pesawat di aplikasi tiket.com. 
Untuk pengujian hipotesis berdasarkan uji $\mathrm{F}$, secara simultan menunjukkan bahwa variabel indpenden X1 dan X2 memiliki nilai Fhitung sebesar 51.318 dan nilai signifikansi sebesar 0,000. Maka diketahui bahwa nilai $f_{\text {hitung }}$ lebih besar dari $f_{\text {tabel }}(3,09)$ dan nilai sig lebih kecil dari 0,05. Hal ini menjelaskan adanya pengaruh variabel Terpaan Iklan (X1) dan Kesadaran Merek (X2) secara bersama-sama atau secara simultan terhadap variabel Keputusan Membeli (Y).

Berdasarkan pengujian dan hasil data yang diperoleh peneliti diatas, dapat disimpulkan bahwa terpaan iklan dan kesadaran merek memiliki pengaruh terhadap keputusan pembelian tiket pesawat di aplikasi tiket.com. Hal ini dapat dilihat dari jawaban 100 responden dengan menggunakan skala likert dimana mayoritas menjawab setuju dari setiap pernyataan yang diberikan oleh peneliti.

Sehingga peneliti dapat menyatakan bahwa penelitian variabel Terpaan Iklan (X1) dan variabel Kesadaran Merek (X2) memiliki pengaruh yang positif dan signifikan terhadap variabel Keputusan Membeli (Y). 


\section{KESIMPULAN DAN SARAN}

\section{A. Kesimpulan}

Berdasarkan hasil dari pengujian korelasi berganda, secara simultan antara variabel Terpaan Iklan (X1) dan Kesadaran Merek (X2) terhadap Keputusan Membeli (Y) terdapat hubungan yang erat dan kuat. Terdapat pengaruh yang positif berdasarkan hasil uji regresi yang sudah dilakukan oleh peneliti. Jika terpaan iklan naik maka keputusan pembelian tiket pesawat di aplikasi tiket.com akan naik pula, demikian juga dengan kenaikan kesadaran merek juga akan meningkatkan keputusan pembelian tiket pesawat di aplikasi tiket.com. Menyatakan jika Ho di tolak, dan Ha diterima berdasarkan hasil uji $\mathrm{F}$ yang telah dilakukan oleh peneliti. Berdasarkan uji F, secara simultan menunjukkan bahwa adanya pengaruh variabel X1 dan X2 secara bersama-sama atau secara simultan terhadap variabel $\mathrm{Y}$.

\section{B. Saran}

Berdasarkan hasl penelitian yang telah dibahas sebelumnya, maka peneliti ingin memberikan saran, yakni:

1. tiket.com selalu membuat iklan yang menarik dan berkualitas. sehingga dapat membuat audience membeli produk yang ada di aplikasi tiket.com. 
2. Membangun kesadaran merek tiket.com agar semakin melekat di kalangan masyarakat luas. Diharapkan tiket.com dapat selalu membuat hal-hal yang baru.

3. Penelitia selanjutnya dapat mengkaji lebih dalam lagi mengenai perkembangan media baru yang semakin berkembang pesat saat ini.

\section{DAFTAR PUSTAKA}

Arifin, Johar. 2017. SPSS 24 Untuk Penelitian dan Skripsi. Jakarta: Elex Media Komputindo.

Bungin, Burhan. 2017. Metode Penelitian Kuantitatif: Komunikasi, Ekonomi, dan Kebijakan Publik Serta IlmuIlmu Sosial Lainnya. Jakarta: Kencana.

Eriyanto. 2011. Analisis Isi: Pengantar Metodologi Untuk Penelitian Ilmu Komunikasi dan Ilmu-Ilmu Sosial Lainnya. Jakarta: Perdana Media Group.

Ferdinand, Augusty. 2014. Metode Penelitian Manajemen. Edisi 5.

Semarang : Badan Penerbit Universitas Diponegoro.

Ghozali, Imam. 2011. Aplikasi Analisis Multivariate dengan Progam SPSS. Semarang: Badan Penerbit Universitas Diponegoro.

Ghozali, Iman. 2013. Aplikasi Analisis Multivariate dengan Program SPSS 21. Semarang: Badan Penerbit Universitas 
Diponegoro.

Hamdi, Asep Saepul dan E. Bahruddin. 2015. Metode Penelitian

Kuantitatif Aplikasi dalam Pendidikan. Yogyakarta:

Deepublish.

Kriyantono, Rachmat. 2012. Teknik Praktis Riset Komunikasi.

Jakarta: Kencana Perdana.

Kriyantono , Rachmat. 2014. Teknik Praktis Riset komunikasi.

Jakarta: Prenada Media.

Littlejohn, Stephen W dan Karen A. Foss. 2011. Theories of

Human Communication. Jakarta: Salemba Humanika.

Morissan. 2013. Teori Komunikasi Individu Hingga Masa.

Pertama. Jakarta: Kencana.

Santoso, Singgih. 2010. Statistik Nonparametik Konsep dan

Analisis dengan SPSS. Jakarta: ElexMedia Komputindo.

Sarjono, Haryadi., dan Julianita, Winda. 2011. SPSS vs LISREL:

Sebuah Pengantar, Aplikasi untuk Riset. Penerbit Salemba empat, Jakarta.

Siregar, Syofian. 2013. Metode Penelitian Kuantitatif Dilengkapi

Dengan Perhitungan Manual dan SPSS. Jakarta: Kencana.

Siregar, Syofian. 2015. Statistika Terapan untuk Perguruan Tinggi.

Jakarta: PT Kharisma Putra Utama.

Sugiyono. 2010. Metode Penelitian Pendidikan. Bandung: Alfabeta.

Sugiyono. 2013. Statistika Untuk Penelitian. Bandung: Alfabeta. 
Sugiyono. 2015. Metode Penelitian Kuantitatif kualitatif dan $R \& D$. Bandung: Alfabeta.

Sugiyono. 2016. Metode Penelitian Kuantitatif, Kualitatif dan $R \& D$. Bandung: PT Alfabet.

Sugiyono. 2019. Metode Penelitian Kuantitatif, Kualitatif, dan $R \& D$. Bandung: Alfabeta.

Widyanto, Joko. 2010. SPSS for Windows Untuk Analisis Data

Statistik dan Penelitian. Surakarta: BP-FKIP UMS.

\section{Jurnal}

Alfiah, Fifit, Yulianto, Eka Purnama Harahap, Baiq Aneji Pahad, Andriyanto, Ian An Azhari, and Riyan Sindi Saputra. 2015. "analisa peranan teknologi internet sebagai media transaksi e-commerce dalam meningkatkan perkembangan ekonomi Yulianto." Semnasteknomedia Online 3(1):4-1-25.

Ali, Hapzi. 2019. "Building Repurchase Intention and Purchase

Decision: Brand Awareness and Brand Loyalty Analysis (Case Study Private Label Product in Alfamidi Tangerang).”

Saudi Journal of Humanities and Social Sciences 04(09):623-34. doi: 10.36348/sjhss.2019.v04i09.009.

Anggana, Raihan Fakhrin, and Idris. 2017. "Analisis Pengaruh Kesadaran Merek, Harga, Dan Promosi Terhadap Keputusan Pembelian Kartu Prabayar XL Di Kalangan Mahasiswa (Studi Pada Mahasiswa Universitas Diponegoro).” 6(1):110. 
Kurnia, Muhammad Rifai. 2016. "Pengaruh Merek, Kualitas Produk Dan Promosi Terhadap Keputusan Pembelian Peralatan Olahraga Tenis Meja Oke Sport Di Kecamatan Wonosari." Jurnal Bisnis Dan Ekonomi (JBE) 24(1):33-42. Martina, Sopa, and Lukmanul Hakim. 2018. "Kesadaran Merek Pengaruhnya Pada Keputusan Pembelian Wisatawan Domestik." Jurnal Ecodemica: Jurnal Ekonomi, Manajemen, Dan Bisnis Universitas Bina Sarana Informatika 2(2):253-62.

Norhabiba, Fitri. 2020. "Pengaruh Terpaan Iklan Marketplace, Akses Aplikasi, Dan Minat Membeli Pada Mahasiswa." Impresi 1(1):16-25.

Paramita Purnama, Rosita Anggraini, Arintowati Hartono, Irwansyah, and Niken F. Ernungtyas. 2019. “Terpaan Iklan Digital, Word Of Mouth Dan Komunikasi Pemasaran Interaktif Pada Keputusan Pembelian Produk Perawatan Tubuh." KOMUNIDA : Media Komunikasi Dan Dakwah 9(2):192-209. doi: 10.35905/komunida.v9i2.1123.

Ramadayanti, Firda. 2019. "Peran Brand Awereness Terhadap Keputusan Pembelian Produk." Jurnal Studi Manajemen Dan Bisnis 6(2):78-83. doi: 10.21107/jsmb.v6i2.6690.

Sari, Niken Permata, and Retno Widowati PA. 2014. "Hubungan Antara Kesadaran Merek, Kualitas Persepsian, Kepercayaan Merek Dan Minat Beli Produk Hijau." Jurnal Manajemen 
Bisnis 5(1):59-79.

Sediyaningsih, Sri. 2018. "Konvergensi Media Di Era Digital (Eksploitasi Media Komunikasi Dalam Proses Belajar Mengajar Di Era Digital)." Jurnal Pendidikan Terbuka Dan Jarak Jauh 19(1):52-57. doi: 10.33830/ptjj.v19i1.317.2018. Tranggono, Didiek, Ajeng Nidita, and Juwito Putri. 2020. "Pengaruh Terpaan Iklan Nacific Di Instagram Terhadap Keputusan Pembelian Produk Nacific Pada Followers Akun @nacificofficial.Id.” Jurnal Komunikasi 10(2):141-55. doi: 10.15642/jik.2020.10.2.141-155.

\section{website}

"Profil Perusahaan Tiket.com" Diambil Ilmu dari https://id.wikipedia.org/wiki/Tiket.com\#: :text=Tiket.com\%20di dirikan\%20oleh\%20Wenas, tiket\%20pesawat\%20dan\%20kereta\% 20api. Diakses pada 15 Mei 2021.

"Logo Tiket.com" Diambil dari https://kumparan.com/kumparantech/tiket-com-ungkap-maknadi-balik-logo-barunya Diakses pada 15 Mei 2021 